DE DE GRUYTER OPEN
Journal of Intercultural Management

Vol. 5, No. 4, December 2013, pp. 81-92

DOI 10.2478/joim-2013-0028

Ryszard Kucha

University of Social Sciences

Mariola Świderska

University of Social Sciences

\title{
Sergiusz Hessen (1887 - 1950) - as creative European educationalist with no homeland
}

\begin{abstract}
This article examines the life and scientific career of the prominent European educationalist and pedagogue Sergiusz Hessen. His pedagogical heritage is examined on the base of basic primary writing and archive sources prepared in different languages. We are trying to show the contribution of the Hessen's activity in the research methodology of multicultural societies and education, his philosophy of education, teaching knowledge, as well as in the real process of university and school education.
\end{abstract}

Key words: Sergiusz Hessen, distinguished international educator, pedagogical values, multicultural heritage.

\section{Introduction}

Strange and complicated indeed was the life of Sergiusz Hessen, born on 16 August, 1887, in Ust'Sysolsk, a one-horse town with county rights which was named Syktykvar during the Bolshevik era to become the capital of the autonomous Komi Republic. It was there that his father served a three-year sentence of forced migration [Okon 1997, p.11]. Admittedly, it seems that the parents of small Sergiusz were not a perfectly-matched couple, the fact being that, with the father having served his sentence, they separated, leaving the youngster to be cared for by his father's relatives in the countryside. There the boy stayed for 2 years. At the age of 5 he was sent to Odessa to live at the house of his father's new fiancée, who had also been through a peculiarly failed marriage which left her with three sons [Okon 1997, p.12]. 
As put by W. Okoń, Sergiusz finally had a stroke of luck. At last he was surrounded by family, had a mother, whom he did not know was his stepmother until long into his life, as well as three brothers, and his father to care for him. Moreover, he was tutored by a governess to develop a good command of French [Okoń 1997, p.12].

At the age of 9, Sergiusz moved with his family to Saint Petersburg, where he attended a middle school to receive a comprehensive education - however, as W. Okon points out - it was thanks to his family home, his father and his personal drive for self-improvement that he achieved most in his life. He also tried his skills at being a proof-reader for a weekly magazine "Prawo" ("The Law") published by his father. This allowed the young Hessen to meet and engage with people both at the editorial office and at his father's study, where the members of the editorial board gathered for meetings. There he also developed and fostered his interest in law and lawfulness. Over that period, Sergiusz went through a crisis of belief and started to take interest in Marxism, which led him to engage in political activity [Okoń 2000, s.147].

\section{The life of a wanderer - searching for a place in the world}

Already at the age of 18 , as he recalled himself, he was a "zealous revolutionary." It is no wonder, therefore, that in 1905 he was sent to study in Heidelberg, eventually moving to Freiburg, where he found himself under the considerate guidance of the much-renowned Heinrich Rickert, with whom he long thought and dreamt of cooperating. There he pursued his academic education under the guidance of eminent scholars, some of whom included G.Jellinek, E.Lasek, W.Windelband, J.Cohn and the previously mentioned H. Rickert. Together with a group of philosophers, he started the magazine called "Logos" which functioned as a press outlet for Neo-Kantians, with whom he himself ideologically identified. At 22, 4 years into his academic education, he wrote and defended an outstanding $\mathrm{PhD}$ dissertation entitled "Kausalitaet. Studien zum transzendentalen Empirismus" ("Causality. A study of transcendental Empirism") under the academic supervision of H. Rickert. By doing so, in 1909, he made his reputation as a man with a perfect command of German. Eventually, the work was published in print, earning its author a summa cum laude honour [Sztobryn 2003, s. 192].

The hard-working nature of a man knowledgeable and interested in many fields was reflected in the fact that the $\mathrm{PhD}$ dissertation was not the only goal he was focussing on to pursue at that time. In 1908, he translated H. Rickert's "Geschichtsphilosophie" ("The History of Philosophy") from German into Russian, and wrote a preface to the Russian issue of the book. Moreover, he wrote a study to comment on the political views represented by the Girondists, and published its translation into French in print, as well as translated 
from French into Russian a number of speeches by Girondists. He was also responsible for the pre-press preparation of the second edition of the Theory of the Unification of States by G.Jelinek. For such a young, albeit intellectuallyrobust scholar, this was an extraordinary achievement that made a strong case for the immensely positive impact that the involvement of foreign, experienced Professors can have on helping a young man find his way into self-development [Okoń 1997, p. 147-148].

In 19010 and 1911, he went on to study in Saint Petersburg, and paid another visit to Germany, this time to Marburg, for one term, to engage in cooperation with P. Natorp, H. Cohen and N. Hartmann. Three years later, this cooperation resulted in earning him the Venia Legendi title [Sztobryn 2003, p. 192]. As was the case over the earlier years, he gave lectures at various universities and translated books into Russian. What's more, he published his own thesis entitled "The Philosophy of Punishment" [Okoń 1997, p. 148].

Having passed all his exams, he started work as an independent lecturer. Over 1913-1917, he gave lectures at the University of Saint Petersburg. It was then, however, that he and his family in Heidelberg found themselves caught in the events of World War I, which broke out at that time. Despite being under arrest for a short time, he managed to make his way to the homeland. Over the period of 1915-1917, he lived in Tsarskoye Selo, where he focussed on preparing for lectures in pedagogy that he started to give in Autumn 1916 [Sztobryn 2003, p. 192].

He discontinued his work there to settle in Tomsk, where for 4 years he worked at the local university as the Head of his Department, as Deputy Dean, and, subsequently, as the Dean of the Department and lecturer in logic, the history of Greek philosophy, ethics, the philosophy of law and pedagogy. It was his academic work in the field of pedagogy there that enabled Hessen to develop a concept for his next book, this time focussing on the analysis of basic pedagogical subjects. Therewithin he laid down his pedagogical system [Okoń 1997, p. 148].

His so-far peaceful existence moved into a more turbulent phase as he went to Moscow and, subsequently, to Petersburg, where he was appointed the Head of the Department of Pedagogy at the local university. The city was in a state of misery, and revolutionary turmoil, combined with the risk of being detained, forced Sergiusz Hessen to move out with his family to Finland, and then to Germany, where at first he stayed in Berlin., to later settle in Jen. It was in Germany that he finished writing his book entitled "The Basics of Pedagogy", published in Berlin in 1923. At the same time, his other two works on F.W. Froeble and Maria Montessori were printed and published in Prague. Also, his dissertations on the concept of the laboratory school and Plato's plan 
saw the light of the day [Okon 1993, p. 148-149]. The previously-mentioned publications helped Sergiusz Hessen earn a Professor's degree at the Russian Institute of Pedagogy in Prague, and, following its discontinuance, received a small scholarship from the Czechoslovakian Government. The scholarship proved crucial in enabling the Hessens to stay in Czechoslovakia for 11 years until 1935. It needs a mention that during his stay in Prague Hessen also engaged in cooperation with the Russian People's Institute and the Russian Society of Philosophy. In 1925, he took an active part in re-launching the "Logos" magazine [Sztobryn 2003, p. 192].

1926 - 1932 was a period of remarkably extensive and effective research and ideological work by this, it goes almost without saying, amazing man. He was invited to give lectures in Paris, Berlin, Warsaw, Cracow, Vilnius, Dresden, Vienna, Leipzig and London. Additionally, he joined several local scientific clubs in Prague, including the Linguists Club, the Philosophy Club and the Czechoslovakian Slavic Institute. What is more, in 1931-1932, he worked at the German University in Prague where he frequently met and discussed issues with R. Carnap. Besides, his frequent visits to universities across Europe allowed him to strike up friendly and direct cooperation with such remarkable pedagogues as Georg Kerschensteiner and N.Hans, with whom he published a book entitled "Pedagogy and the school system in Soviet Russia." He also wrote and published a series of articles on "the issue of lawfulness in Socialism". The articles were presented in "Sowriemienne Zapiski", a newspaper printed and published in Paris. There he contrasted the concept of nationalising the economy with, as W. Okon put it, "lawfullising" the State and the economy. Hessen's robust academic activity abroad can be partly explained by his austere financial situation, as the scholarship he received from the Czech Government was regrettably very scant [Okoń 1997, p. 149].

Hessen also managed to establish enduring contacts with the Polish scholars Tadeusz Kotarbinski (1926) and A. Zieleńczyk (1930). These personal relationships and friendships were most probably crucial to his decision in 1933 to visit Poland with a series of lectures on school reform in Czechoslovakia, as well as on pedagogy in Soviet Russia. These appearences in front of an audience of 600 people encouraged him to accept the proposal to take up the position of Professor at the Free Polish University in Warsaw and the position of the Head of the Department of Philosophy of Education at the same university. This, however, did not mean that he was about to permanently settle in Poland. It was when family-related and financial problems started to mount up that he made up his mind to settle in Poland in 1936 and assume Polish citizenship. What he was confronted with was a problem analogous to that which he faced during his stay in Prague - there he had to learn Czech, here it was Polish. 
A major help in that respect was provided to him by his numerous friends in Poland, in particular Maria Niemyska, who - having got divorced - became his wife. The stay in Poland also resulted in establishing connections with the "Gabriel Narutowicz" masonic lodge and active participation in the "Tusculum" club, where he elaborated on didactics-related issues. It is worth adding that the membership of the club was meant for those with a so-called higher level of insight [Okoń 1997, p. 149].

Thence a period of prosperity and peace, full of research, writing and didactic work, dawned in his life. All in all, this was the most prolific time in a life full of trials and tribulations which a man with no homeland like him to endure. As part of his didactic work at the Free University of Poland he had to travel between Warsaw and Łódź. Additionally, he held assigned seminars at Warsaw University and at the Institute of Special Pedagogy in philisophy of education, comparative pedagogy and educational psychology.

Over the first four years of his stay in Poland, two monographies by him were published in print: "The school and democracy at breaking point" and "Consistencies and Inconsistencies in Education". "The structure and the content of the contemporary school", another important work of his, was also brought to print. The book provided an competent outline of the philosophy of education. Yet, as World War II broke out in 1939 and Poland were invaded (the September Campaign), Hessen and his family were to experience extreme difficulties for the next 6 years. It was typical for a scholar in those times of wickedness to give private lessons to a miller's or a teacher's children, organise secret classes for children in the countryside and in Warsaw, attend illegal seminars, and supply the family with the essential victuals and materials for heating [Okon 1997, p. 16]. Worth mentioning is the fact that Hessen resided in Warsaw as the war dawned, but - out of fear of being detained - he had to leave the city. He returned there in 1941, after the breakout of war between Hitler's Nazi Germany and Stalin's Soviet Union. And yet again clandestine scholarly meetings were held in his flat, involving numerous eminent scholars: Bogdan Suchodolski and Bogdan Nawroczyński as well as Tadeusz Kotarbiński, Władysław Tatarkiewicz and others. Moreover, S. Hessen provided refuge at his flat for many people who were being pursued by the Gestapo [Sztobryn 2003, p. 192].

Hessen was an up and doing underground activist. During the Nazi occupation, he held 20 series of illegal lectures, with 9-15 seminars for each. He established connections with the underground press, including the "Pismo Młodych" (The Youth Magazine) as an outlet of the Szare Szeregi (Grey Ranks). Unsurprisingly, therefore, he was arrested in 1943 and sent with his wife to the prison in Radom. It was by a lucky coincidence that they were released this 
time, but a year later, during the Warsaw Uprising, they were captured at the hands of the Russian Liberation Army soldiers to one again face death \{Ibidem, p. 193].

Being forced to continuously change his place of living and having to cope with a permanent threat to his existence, Hessen had a hard time continuing and developing his research and writer's work, yet he did not discontinue it totally. He made attempts at writing, but his works fell victim to an overwhelmingly cruel fate, perishing in the course of the Warsaw Uprising. Having miraculously escaped death during the Warsaw Uprising, the Hessens went to Czeladź, where a sister of Hessen's wife, Maria lived. There he undertook employment as a store-keeper at a warehouse for metal products run by some Volksdeutscher. There he went back to his creative work and wrote a piece on the essence and mission of the law. The first chapter of this work, entitled "Law and morality", was published in several languages, including Polish, published later, in 1948 [Okoń 1997, p. 17].

In the wake of the Nazi occupation within Poland's territories, the threads of destiny led Hessen Łódź, invited by the rector of the re-launched Free Polish University, to continue their cooperation. Despite the times being still harsh, it is here that he could finally find relative a peace of mind. It should be remembered, however, that the condition the wanderer of our interest was in as he came to Łódź was pitiable, being emaciated and sickly. Treated by doctors and cared for by his wife, as well as accommodated in a cosy apartment located in the city centre, though, he recovered quickly, to regain strength, both physical and mental. Nonetheless, he then received the sad news of the death of his first wife, and his son Eugeniusz, who was an up-and-coming talented poet. It was there that he also learned that his father and older brother had died as well, in Paris, at the hands of the Germans. All this distress, magnified by the harsh experiences he endured during the occupation, contributed to a severe heart condition, which this remarkable researcher and thinker regrettably downplayed. Despite having lost $50 \%$ of his health, he did not abandon his work, and went on to smoke tobacco and consume copious amounts of coffee [Ibidem, p. 17]. What the amazing wanderer of our interest did not choose to give up was also the editorial and writer's work that meant life to him. He introduced corrections to his monography entitled "The Structure and the Content of the Contemporary School", and had it published in 1947. He also wrote two more theoretical dissertations in English - "Slavonic Countries" (1948) and "Education and Economic Life" (1989). Both were published in print in the "International Yearbook of Education". Almost at the same time he managed to prepare a new piece entitled "The Rights of Man in Liberalism, Socialism and Communism." It was published in 1949 in London [Ibidem, p. 17-18]. 
When describing the life and scholarly work of Sergiusz Hessen one must mention his life as a wanderer, and a vast output both as a researcher and writer, as well as his special respect towards all people who thought independently and creatively at the same time. He lived his life in hard times, a life that abounded in highly-distressing experiences that lead to his health failure and, consequently, accelerated his death, as he, full of hope and zeal, seemed primed to pave his way into new fields of thought of his own and his students - who were abundant, particularly during the Łódź period. When holding seminars and scholarly meetings with fellow scholars he always had them in mind and treated them with due respect. He was a Master for them, and they felt greatly honoured by the possibility of associating with him. The effectiveness of his education is reflected in the fact that he taught a number of students who would later become titular Professors: Aleksander Kamiński, Janina Koblewska, Karol Kotłowski, Józef Kozłowski, Miron Krawczyk Tadeusz Nowacki, Wiktor Szczerba and Wincenty Okoń. It was they who went to work at the University of Łódź, the University of Warsaw, Maria Curie-Skłodowska University, and other universities, to keep a thankful memory of their Master alive [Ibidem, p. 18].

However, it was not Sergiusz Hessen's destiny to live a long and fully happy life. Having established his bond with Poland by settling there and assuming Polish citizenship, he would surely see - in particular during the time after World War II when our country fell within the sphere of influence of the Stalinist Moscow - the negative political and economic changes attributable to the Stalinist era. Confronted with reality, his dreams of the ideal socioeconomic system that he wrote about in his dissertations must have been shattered, which surely must have caused his health to deteriorate. Having been additionally dismissed from the position of the Head of the Department of Pedagogy for obvious political reasons, all he could do was to start working as a lecturer in the Russian Philology Department, a position for which he was perfectly prepared as an expert in Russian literature and Slavic languages. Such a description of this period of his didactic work was described by A. Walicki: "As for a man of his age, it was remarkable to see his passion as he held seminars for freshmen. He contemplated the sagacity of the structure of language, its philosophical nature - his linguistic analyses were coupled with strictly philosophical digressions. It also had an air of aesthetic attitude. Hessen was particularly struck by the beauty of the Old Church Slavic archaisms, mostly by calques from Greek. His philosophical-linguistical analyses were based on Russian poetry." [Walicki 1968, p. 44].

His zeal and passion for work were relentless, something he probably achieved through going on vacation in Polanica Zdrój or Niechorz. A chronic angina pectoris, though, systematically undermined his health and, although 
not discontinuing his work at the university and remaining in touch with the academic community until the end- as late as a few days before he died, he gave a lecture in Torun - he died an unexpected, albeit painless and peaceful death. After his death he was taken to Warsaw, a city to which he was tied in many ways. At first he was buried at the Orthodox Church Cemetery in Łódź, but later his ashes were moved to Powązki cementary in Warsaw [Okoń 1997, p. 153].

\section{Sergiusz Hessen's wandering of mind following his life's wandering}

The scholar and homelandless scholar of our interest could not have anticipated that his stream of thought would continue to last and, it seems, will never cease to do so. For if we assume that Hessen's "life after life" is only a memory of himself and his works published both before his death and posthumously, that he belongs to the past, as with new times fresh challenges emerge for all the living, then what would be the response of those who were taught by him directly, those who were trying to keep the treasures of his thought in the memory of future generations. Why are there so few followers of Hessen, since his thoughts are addressed to pedagogues, philosophers, legal scholars and all professionals who deal with culture? Why is it that the country which allowed him to finally settle permanently for the remaining dozen years of his life, where Hessen's legacy, powerhouse of deep thought, insight and broadmindedness, acclaimed by many a foreign scholars, should be etched upon the memory of people, is so astonishingly reluctant to keep the legacy alive?

However, the one to blame for this deplorable fact is largely his mother country, which condemned him for criticising the political system of the Soviet Union, for his educational reforms, his views on the freedom of man and the political system of the Russian country, and for the mere fact of him deciding to stay an emigrant. This way Hessen, as a Russian and patriot, was sentenced to fall into oblivion for many years, almost until the collapse of the Soviet Union. Then, a natural chain reaction followed, erasing him into oblivion in the countries which were under the Soviet influence at that time. Is there any hope for Hessen's legacy to be objectively and reliably judged by contemporary Russian researchers? Admittedly, so many years after the Soviet Union collapsed to disperse into a profusion of new independent countries, it is difficult to assess precisely whether the process of bringing back the remarkable pedagogical and philosophical legacy of Sergiusz Hessen will gain momentum in the Russian Federation. For not all social and political transformations in this still largest country in the world may be seen as conducive to the process [Ibidem, p. 154]. 
The most eloquent assessment of his works' values was made by the Polish philosopher A. Walicki, who said: "As a testimony to the era - so close to us, and yet belonging to the historical past they were written in, these documents are definitely interesting and have educational value. We could learn a great deal from them - even if we dismiss the philosophical assumptions put forward in them. Last but not least, we may see them as an attempt at fostering certain principal values rooted in the tradition of humanities which, however differently explained, should be known to each of us" [Walicki 1968, p. 44]. A similar assessment of Hessen's creative legacy was recently provided by the recentlydeceased Prof. Tadeusz Nowacki. He claimed the following: "A study of Hessen's theories and concepts is essential to the self-awareness of every pedagoguetheoretician, for such a demanding intellectual challenge as Hessen's theory of education constitutes requires those who explore it not only to get acquainted with it, contemplate it and derive what is most important from it, but also to develop one's own standpoint with regard thereto in order to overcome it at the next stage of its development, while keeping what is true and valuable about it, what resists the ever-growing inundation of the human thought as it continues to progress rapidly... Such was the dialectic of development from Hessen's point of view. And, given the fact that it is in many ways linked to idealism, it can be claimed that it should be an obligatory starting point for young materialistic pedagogues in order for them to attain important elements of theoretical selfknowledge." [Okoń 1997, p. 156]

Another monography published in Poland, fully dedicated to S.Hessen, was written by S.Sztobryn. Therein its author, who himself derived from the Łódź community, focussed on the issue of the philosophy of education by this European pedagogue [Sztobryn 1994, p. 201]. The end of the $20^{\text {th }}$ century saw at last another volume of selected works by $\mathrm{S}$. Hessen published in Poland. It was published in five volumes by the "Żak" publishing house, with the first volume featuring Hessen's “The Basics of Pedagogy” [Hessen 1997, p.23].

The memory of Sergiusz Hessen was kept not only in Russia, but also in foreign countries. It included studies by H.Meyer-Bohling, G.Broccolini, and Liga Volpicelli. Also the works by Hessen himself were published, especially in the interwar period. His elaborations were published in English, Bulgarian, Czech, French, Serbian, Slovakian, Russian (outside the territory of Russia) and - obviously - in Polish. In the wake of World War II, a number of smaller studies on Hessen by L.Froese and L.Liegle was published, in which the latter expressed touching words as he recalled Hessen as one of the greatest intermediaries between the Western and Eastern traditions of thought and political culture. As such, Hessen was always serving the truth, which he pursued persistently and had his own way of finding it, and when he did, was ready to share it with the readers of his books and articles published in many languages [Ibidem, p. 25]. 


\section{The value and originality of Sergiusz Hessen's theories today}

We usually associate scholarly and research work with the methodology used by a given scholar in seeking truth. And there the methodological inspirations of Hessen are related to the works he translated from German. H. Rickert was his ultimate inspiration whose guidance helped Hessen prepare and defend his $\mathrm{PhD}$ dissertation. Already, in "The Basics of Pedagogy", Hessen's intellectual bond to Rickert's philosophy and the philosophy of his master W.Windelband, was evident. Hessen saw pedagogy as part of cultural sciences which led him to establishing its methodological status, for in his mind it was an idiographic science, with its sphere of exploration being values as individual and unique goods. With regard to pedagogy, its scope of research includes not only education and the environment, the educator and curriculum, but also their types and standards for their development, as well as their dynamic and the organisation necessary to fulfil educational goals and tasks. However, these educational goals are not something accomplished and ultimate, but are open to change, something which is not so much taken for granted as something which is assigned and requires further dynamic and development. Therefore, for him the goals were identifiable with unconditional values that in a particular constellation formed a culture.

Hence, what should be of interest to a pedagogue in an the individual biography of man and his personality is only the past facts bearing relation to extrapersonal tasks which are subject to a human's creation, his calling and service to extrapersonal values. In his opinion, what is individual remains irreplaceable and unique. Therefore, Hessen claims that the educator's task is not so much to provide knowledge and to develop skills as to make much more, to "make someone being like you." [Ibidem, p. 26-27]

In the course of his pedagogical research and analyses Sergiusz Hessen applied a dialectic method based on foundations drawn from Plato and elaborated by Hegel, from whom he adopted the idea of development as a three-stage process of overcoming contradictions, including a thesis, an antithesis and a synthesis. His assumption also was that another, higher, stage in this process is equal to a higher stage of development, which means not only the need to overcome the flaws of the previous stage, but at the same time to preserve the values imbued therein [Ibidem, p. 28].

Worth adding is the fact that the basic foundations of the pedagogic system developed by S. Hessen were already formed in the period of his stay in Tomsk to later be completed during his visit to Berlin. His "The Basics of Pedagogy" from 1923 set the general direction for pedagogical research within the respective sub-fields of pedagogy which he himself was interested in, that is, general pedagogy, comparative pedagogy, the history of pedagogical theory, 
and didactics. The basic foundations of his philosophy of education were formed a lot earlier, and could already be observed in the PhD dissertation which he wrote under the guidance of $\mathrm{H}$. Rickert. Hessen's "Philosophy of Punishment" also verified not only the concept of applied philosophy, but also indicated its presence in pedagogy. It also touched on the subject of the freedom and subjectivity of human beings.

As far as the philosophy of education is concerned, Hessen developed a very coherent system based on the Baden School of Neokantism. Rather than being a compilation of randomly-assumed hypotheses, his philosophy aimed at analysing the premises inherent in experience. Hessen called his standpoint Transcendental Empirism. In his mind philosophy was about values [Sztobryn 2003, p. 193].

Being an enquiring and crafty explorer of works by Wilhelm Dilthey, Heinrich Rickert and Wilhelm Windelband, Hessen placed pedagogy among cultural sciences, while at the same time positioning it in the indiograhical field. To make things clear, it was precisely the values that his entire intellectual structure were revolving around, for they functioned as the creations of human work, both in material and spiritual terms, which made their nature objective. Hence, if through individual creative work people live their life to realise certain values that are not created by them, because they are only capable of interpreting these values and placing them in the context of their culture, then it means that both philosophy and other disciplines are at the heart of pedagogy and all its sub-disciplines. Hence from Hessens perspective the theory of moral and lawful education stems from philosophy and ethics, the history of pedagogical theory stems from the history of philosophy, and the theory of religious education is anchored in the philosophy of religion. Thus, the ultimate goal with regard to the education of new generations remains within the domain of the pedagogy of culture, which is intended to introduce them to the world of values and cultural goods, to foster their development at a hermeneutical level and consequently to allow them to use this insight in developing their individual personality and autonomy [Ibidem, p.194].

\section{Instead of a conclusion}

Engaging in the analysis of pedagogical views formulated by Sergiusz Hessen is a difficult task in these contemporary times. However vital it may remain nowadays, it still is controversial and often makes new attempts at reinterpreting it fail. Nonetheless, Hessens remains an interesting figure whose ideas - known within the domain of European pedagogy - may be used for purposes which are not necessarily educational. His pedagogy, however, still provides a valuable contribution to the axiology and various pedagogical 
fields in the contemporary world, and is of relevance to advocates of general global education [see to: Świderska 2011, p. 7-8].

\section{Bibliography}

Hessen S. (1997), The basics of pedagogy, Warsaw 1997.

Okoń W. (1997), Sergiusz Hessen jako cztowiek i uczony (Sergiusz Hessen - a man and a scholar) [In:] S. Hessen Podstawy pedagogiki (The Basics of Pedagogy) Selection and editing by W. Okoń. Warsaw.

Okoń W. (2000), The biographies of famous Polish Pedagogues, Warsaw.

Sztobryn S. (2003), Sergiusz Hessen (1887 - 1950), Encyklopedia Pedagogiczna XXI wieku (Encyclopedia of Pedagogy). Eds. T. Pilch. Warsaw, vol. 2.

Sztobryn S. (1994), The philosophy of education by Sergiusz Hessen, Łódź.

Świderska M. (2011), Selected Problems of Social Exclusion, Lodz.

Walicki A. (1968), S. Hessen: Studies of the Philosophy of Culture. Selected, prefaced and annotated by A. Walicki, Warsaw. 